\title{
HEALTH BEHAVIOURS OF PATIENTS WITH CIRRHOSIS
}

\author{
Bożena Baczewska ${ }^{1}$, Beata Kropornicka ${ }^{1}$, Joanna Seweryn, Ewa Krzyżanowska ${ }^{1}$, \\ Elżbieta Nowicka ${ }^{1}$, Jadwiga Daniluk ${ }^{2}$
}

\author{
${ }^{1}$ Chair of Internal Medicine and Department of Internal Medicine in Nursing, Medical University in Lublin \\ ${ }^{2}$ Department of Health, Pope John Paul II State School of Higher Education in Biała Podlaska
}

Baczewska B., Kropornicka B., Seweryn J., Krzyżanowska E., Nowicka E., Daniluk J. (2015), Health behaviours of patients with cirrhosis. Health Problems of Civilization, 4 (9), p. 32-39.

\begin{abstract}
Summary: The aim of the study was to investigate and compare the health behaviours of patients with cirrhosis. The study was conducted from February to June 2012. Before starting the study, the consent was received by the Bioethics Committee at the Medical University of Lublin. The group of 92 patients with cirrhosis was examined, in Świętokrzyskie, Lubelskie and Mazowieckie voivodeships. The main criteria of selection were: known cirrhosis during the hospital treatment and acceptance for participation in the study.

The Health Behaviour Inventory (IZZ) by Juczyński was extracted in the study. It contains 24 statements that describe the various types of health-related behaviours and are divided into 4 categories describing health behaviours. For the purposes of the evaluation such behaviours as: proper eating habits, proactive behaviours, health practices and positive mental attitude have been defined. The study group was characterized by average health behaviors, the results were within the 5 and 6 Sten. Studies have shown a higher intensity of health behaviors in the category of a positive mental attitude and proactive behaviour, while less intensity was visible in the category of proper eating habits and health practices.

It has been shown that there are statistically significant differences between health behaviour, gender and age of the respondents. Women had significantly higher intensity of correct eating habits and proactive behaviours. Respondents aged 51 years old or older had the best health behaviours in all the categories of health behaviours. The study showed no statistically significant differences between health behaviour and the time of diagnosis, place of residence and education of the respondents.
\end{abstract}

Keywords: health behaviours, cirrhosis, patient

\section{Introduction}

Cirrhosis is the final phase of many liver's chronic diseases. Their causes are various. It is assumed that incidence of cirrhosis is 200-300/100.000 inhabitants. Cirrhosis is an irreversible process, but the progress of the disease can be slowed down if its cause is detected and fought. Adherence to dietary and curative recommendations lets the patients stay in good condition for months and years (Mach 2005, WawrzynowiczSyczewska 2011). Health behaviors are among the most important factors that determine the human health (Romanowska-Tołłoczko 2011). Review of many definitions and classifications of health behaviours in the literature was conducted by: Gniazdowski (1990), Żołnierczuk-Glass (2002) Banaszkiewicz, Andruszkiewicz (2008). Health behaviours during illness cover all human activities that affect the process and the results of the treatment. In the event of the occurrence of obvious symptoms of the disease a human being attempts to remove them. This is called health behaviours in the role of a patient (Żołnierczuk-Glass 2002). Among the healthpromoting behaviours there are four groups of behaviours: related to physical health, psychosocial, proactive, and lack of risky behaviour (Ostrowska 1999).

The aim of the study was to investigate and compare the health behaviours of patients with cirrhosis.

\footnotetext{
Address for correspondence: Bożena Baczewska, Chair of Internal Medicine and Department of Internal Medicine in Nursing, Medical University in Lublin, Jaczewskiego 8, 20-950 Lublin, phone: +48 81742 5825, e-mail: baczewska@o2.pl

Tables: 11 Figures: 0 References: 9 Full-text PDF www.hpc.edu.pl Copyright $\subset$ C Pope John Paul II State School of Higher Education in Biała Podlaska,Sidorska 95/97, 21-500 Biała Podlaska Indexation: Index Copernicus, AGRO, ProQuest, Polish Medical Bibliography, Polish Ministry of Science and Higher Education. This is an open-access article distributed under the terms of the Creative Common Attribution Non-commercial license (http://creativecommons.org/licenses/by-nc/3.0), which permits use, distribution and reproduction in any medium, provided the original works is properly cited, the use is non-commercial and is otherwise in compliance with the license.
} 


\section{Material and methods}

The study was conducted from February to June 2012. Before starting the study, the

consent was received by the Bioethics Committee at the Medical University of Lublin. The group of 92 patients with cirrhosis was examined, in Świętokrzyskie, Lubelskie and Mazowieckie voivodeships. The respondents were treated in the following institutions: the Military Hospital in Lublin, Independent Public Clinical Hospital No. 4 in Lublin, Hospital in Ostrowiec Świętokrzyski, Provincial Amalgamated Hospital in Kielce, Independent Public Central Clinical Hospital in Warsaw, Provincial Specialist Hospital in Radom.

The main criteria of selection were: known cirrhosis during the hospital treatment and acceptance for participation in the study. Detailed profile of the study group is presented in table 1.

Table 1. The profile of the study group

\begin{tabular}{|c|c|c|c|}
\hline \multicolumn{2}{|c|}{ Social-demographic factors } & Number of people & $\%$ \\
\hline \multirow{2}{*}{ Gender } & Men & 44 & 47.83 \\
\hline & Women & 48 & 52.17 \\
\hline \multirow{3}{*}{ Age } & to 40 years & 34 & 36.96 \\
\hline & 41- 50 years & 29 & 31.52 \\
\hline & 51 years and more & 29 & 31.52 \\
\hline \multirow{3}{*}{ Place of residence } & to 100 thousands of residents & 37 & 40.22 \\
\hline & over 100 thousand of residents & 31 & 33.70 \\
\hline & village & 24 & 26.08 \\
\hline \multirow{4}{*}{ Education } & $\begin{array}{c}\text { basic/ } \\
\text { vocational }\end{array}$ & 24 & 26.09 \\
\hline & secondary & 27 & 29.34 \\
\hline & Bachelor studies & 10 & 10.87 \\
\hline & Master studies & 31 & 33.70 \\
\hline
\end{tabular}

Source: own elaboration.

Most respondents (52.17\%) were men. The average age of respondents was $44.86 \pm 14.31$ years.

The largest group constituted patients from cities (40.22\%) to 100 thousands of residents with higher education $44.57 \%$. The average time from diagnosis was $6.47 \pm 4.17$ years.

The Health Behaviour Inventory (IZZ) by Juczyński was extracted in the study. It contains 24 statements that describe the various types of health-related behaviours and are divided into 4 categories describing health behaviours. For the evaluation such behaviours are included as: proper eating habits, proactive behaviours, health practices and positive mental attitude. Health bevaviours which were adverted in questionnaire IZZ were evaluated by the respondents. The respondents used the following scale: 1-barely ever, 2-rarely, 3-from time to time, 4- often, 5- Almost always.

The results of the studies gave a chance to characterize the intensity of the behaviours of patients with cirrhosis that may be defined as pro-health.

Numerical values chosen by patients were added up to receive the index number of intensity of health behaviours. Its value could be in the range from 24 to 120 points. The higher the index number, the greater the intensity of selected health behaviours. The general index number after change to standard units, was submitted to interpretation according to the properties which characterize the scale sten. The results in the range of 1-4 Stena were interpreted as low, 5 and 6 as average, while 7-10 as high. The intensity of the four categories of health behaviours was calculated separately - the index number was the average number of points in each category- the sum divided by 6.

The received results were statistically analyzed. The values of the analyzed measurable parameters were shown via the average value and standard deviation and for non-measurable ones by means of the count and proportion. For measurable traits analyzed parameters of normality distribution was evaluated using the Shapiro-Wilk test. For comparison of two independent groups Student t-test was used. For more than two groups analysis of variance was applied. For qualitative unrelated characteristics in order to detect the existence of differences between groups compared homogeneity test was used $\chi^{2}$. To examine whether there is a relationship between the measured traits the independence $\chi^{2}$ test was used.

The level of significance $\mathrm{p}<0.05$ indicating the existence of statistically significant differences or relationships was assumed. Database and statistical surveys were conducted based on computer software STATISTICA 8.0 (StatSoft, Poland) 


\section{Results of the study}

The study showed that respondents showed varied eating habits. The results are presented in table 2 .

Table 2. Eating habits of respondents by IZZ

\begin{tabular}{|c|c|c|c|c|c|c|c|c|c|c|c|c|}
\hline \multirow{3}{*}{$\begin{array}{l}\text { Parameter } \\
\text { of behaviour }\end{array}$} & \multicolumn{12}{|c|}{ Responses } \\
\hline & \multicolumn{2}{|c|}{ Barely ever } & \multicolumn{2}{|c|}{ Rarely } & \multicolumn{2}{|c|}{$\begin{array}{c}\text { From time to } \\
\text { time }\end{array}$} & \multicolumn{2}{|c|}{ Often } & \multicolumn{2}{|c|}{$\begin{array}{l}\text { Almost } \\
\text { always }\end{array}$} & \multicolumn{2}{|c|}{ Total } \\
\hline & $\mathbf{n}$ & $\%$ & $\mathbf{n}$ & $\%$ & $\mathbf{n}$ & $\%$ & $\mathbf{n}$ & $\%$ & $\mathbf{n}$ & $\%$ & $\mathbf{n}$ & $\%$ \\
\hline $\begin{array}{c}\text { 1.I eat a lot of fruit and } \\
\text { vegetables }\end{array}$ & 7 & 7.61 & 15 & 16.30 & 19 & 20.65 & 32 & 34.78 & 19 & 20.66 & 92 & 100.00 \\
\hline $\begin{array}{l}\text { 5.I avoid animalistic fat } \\
\text { and sugar }\end{array}$ & 18 & 19.57 & 14 & 15.22 & 22 & 23.91 & 18 & 19.57 & 20 & 21.73 & 92 & 100.00 \\
\hline $\begin{array}{c}\text { 9. I care about good nutri- } \\
\text { tion }\end{array}$ & 10 & 10.87 & 17 & 18.48 & 24 & 26.09 & 28 & 30.43 & 13 & 14.13 & 92 & 100.00 \\
\hline $\begin{array}{l}\text { 13. I avoid food with } \\
\text { preservatives }\end{array}$ & 15 & 16.30 & 15 & 16.30 & 26 & 28.26 & 21 & 22.82 & 15 & 16.30 & 92 & 100.00 \\
\hline $\begin{array}{l}\text { 17. I avoid salt and salty } \\
\text { food }\end{array}$ & 16 & 17.39 & 15 & 16.30 & 23 & 25.00 & 17 & 18.48 & 21 & 22.83 & 92 & 100.00 \\
\hline $\begin{array}{l}\text { 21. I eat granary bread- } \\
\text { stuff }\end{array}$ & 17 & 18.48 & 20 & 21.74 & 25 & 27.17 & 17 & 18.48 & 13 & 14.13 & 92 & 100.00 \\
\hline
\end{tabular}

Source: own elaboration.

The analysis of data shows that the proportion of responses where respondents barely ever evinced positive eating habits was $15 \%$, while the proportion of respondents who Almost always evinced them was higher and amounted to $18.3 \%$.

Proactive behaviours were related to adherence to health recommendations, obtaining information connected with health and disease. Table 3 presents the results of analyzed proactive behaviours.

Table 3. Proactive behaviours of respondents by IZZ

\begin{tabular}{|c|c|c|c|c|c|c|c|c|c|c|c|c|}
\hline \multirow{3}{*}{$\begin{array}{l}\text { Parameter } \\
\text { of behaviour }\end{array}$} & \multicolumn{12}{|c|}{ Responses } \\
\hline & \multicolumn{2}{|c|}{ Barely ever } & \multicolumn{2}{|c|}{ Rarely } & \multicolumn{2}{|c|}{$\begin{array}{c}\text { From time to } \\
\text { time }\end{array}$} & \multicolumn{2}{|c|}{ Often } & \multicolumn{2}{|c|}{$\begin{array}{l}\text { Almost } \\
\text { always }\end{array}$} & \multicolumn{2}{|c|}{ Total } \\
\hline & $\mathbf{n}$ & $\%$ & $\mathbf{n}$ & $\%$ & $\mathbf{n}$ & $\%$ & $\mathbf{n}$ & $\%$ & $\mathbf{n}$ & $\%$ & $\mathbf{n}$ & $\%$ \\
\hline 2. I avoid gegtting colds & 6 & 6.52 & 11 & 11.96 & 28 & 30.43 & 25 & 27.17 & 22 & 23.92 & 92 & 100.00 \\
\hline $\begin{array}{l}\text { 6. I have written down } \\
\text { telephone numbers of } \\
\text { emergency medical } \\
\text { service }\end{array}$ & 24 & 26.09 & 14 & 15.22 & 17 & 18.48 & 15 & 16.30 & 22 & 23.91 & 92 & 100.00 \\
\hline $\begin{array}{l}\text { 10.I respect doctor's rec- } \\
\text { ommendations which are } \\
\text { results of tests. }\end{array}$ & 4 & 4.35 & 9 & 9.78 & 21 & 22.83 & 32 & 34.78 & 26 & 28.26 & 92 & 100.00 \\
\hline $\begin{array}{c}\text { 14.I regulary conduct } \\
\text { tests. }\end{array}$ & 14 & 15.22 & 18 & 19.57 & 15 & 16.30 & 21 & 22.84 & 24 & 26.09 & 92 & 100.00 \\
\hline $\begin{array}{l}\text { 18.I try to learn how oth- } \\
\text { er people avoid diseases. }\end{array}$ & 20 & 21.74 & 23 & 25.00 & 20 & 21.74 & 17 & 18.48 & 12 & 13.04 & 92 & 100.00 \\
\hline $\begin{array}{l}\text { 22. I try to get medical } \\
\text { information and under- } \\
\text { stand the reasons behind } \\
\text { health and disease }\end{array}$ & 15 & 16.30 & 15 & 16.30 & 21 & 22.83 & 23 & 25.00 & 18 & 19.57 & 92 & 100.00 \\
\hline
\end{tabular}

Source: own elaboration.

Upon the review of all proactive behaviours it was noted that the proportion where respondents barely ever evinced proactive behaviours was $15 \%$, while cases where they evinced them almost always were much higher and amounted to $22.46 \%$

Positive mental attitude of health behaviours is mainly avoidance of too strong emotions, stress and tension, care of one's health, orderly life. Detailed results are presented in table 4. 
Table 4. The positive mental attitude of respondents by IZZ

\begin{tabular}{|c|c|c|c|c|c|c|c|c|c|c|c|c|}
\hline \multirow{3}{*}{$\begin{array}{l}\text { Parameter } \\
\text { of behaviour }\end{array}$} & \multicolumn{12}{|c|}{ Responses } \\
\hline & \multicolumn{2}{|c|}{ Barely ever } & \multicolumn{2}{|c|}{ Rarely } & \multicolumn{2}{|c|}{$\begin{array}{c}\text { From time to } \\
\text { time }\end{array}$} & \multicolumn{2}{|c|}{ Often } & \multicolumn{2}{|c|}{$\begin{array}{l}\text { Almost } \\
\text { always }\end{array}$} & \multicolumn{2}{|c|}{ Total } \\
\hline & $\mathbf{n}$ & $\%$ & $\mathbf{n}$ & $\%$ & $\mathbf{n}$ & $\%$ & $\mathbf{n}$ & $\%$ & n & $\%$ & $\mathbf{n}$ & $\%$ \\
\hline $\begin{array}{c}\text { 3.I consider seriously } \\
\text { the tips of people who } \\
\text { are concerned about my } \\
\text { health }\end{array}$ & 5 & 5.43 & 14 & 15.22 & 26 & 28.26 & 30 & 32.61 & 17 & 18.48 & 92 & 100.00 \\
\hline $\begin{array}{l}\text { 7. I avoid situations that } \\
\text { are depressing for me }\end{array}$ & 9 & 9.78 & 21 & 22.83 & 29 & 31.52 & 24 & 26.09 & 9 & 9.78 & 92 & 100.00 \\
\hline $\begin{array}{l}\text { 11.I try to avoid emotions, } \\
\text { stress and tension }\end{array}$ & 4 & 4.35 & 16 & 17.39 & 30 & 32.61 & 28 & 30.43 & 14 & 15.22 & 92 & 100.00 \\
\hline $\begin{array}{l}\text { 15.I have friends and } \\
\text { a settled social life }\end{array}$ & 6 & 6.52 & 5 & 5.43 & 21 & 22.83 & 26 & 28.26 & 34 & 36.96 & 92 & 100.00 \\
\hline $\begin{array}{l}\text { 19. I avoid anger, fear and } \\
\text { depression }\end{array}$ & 7 & 7.61 & 22 & 23.91 & 24 & 26.09 & 30 & 32.61 & 9 & 9.78 & 92 & 100.00 \\
\hline 23.I stay positive & 2 & 2.17 & 7 & 7.61 & 25 & 27.17 & 31 & 33.70 & 27 & 29.35 & 92 & 100.00 \\
\hline
\end{tabular}

Source: own elaboration.

Proportion of all responses where respondents barely ever evinced a positive mental attitude was 5.97\%, and those who almost always cared about positive mental attitude amounted to $19.92 \%$.

Health Practice expresses predominantly care of one's own physical health. The full picture of these behaviours is presented in table 5 .

Table 5. Health practice of respondents by IZZ

\begin{tabular}{|c|c|c|c|c|c|c|c|c|c|c|c|c|}
\hline \multirow{3}{*}{$\begin{array}{l}\text { Parameter } \\
\text { of behaviour }\end{array}$} & \multicolumn{12}{|c|}{ Responses } \\
\hline & \multicolumn{2}{|c|}{ Barely ever } & \multicolumn{2}{|c|}{ Rarely } & \multicolumn{2}{|c|}{$\begin{array}{c}\text { From time to } \\
\text { time }\end{array}$} & \multicolumn{2}{|c|}{ Often } & \multicolumn{2}{|c|}{$\begin{array}{l}\text { Almost } \\
\text { always }\end{array}$} & \multicolumn{2}{|c|}{ Total } \\
\hline & $\mathbf{n}$ & $\%$ & $\mathbf{n}$ & $\%$ & $\mathbf{n}$ & $\%$ & $\mathbf{n}$ & $\%$ & $\mathbf{n}$ & $\%$ & $\mathbf{n}$ & $\%$ \\
\hline 4.I rest enough & 7 & 7.61 & 24 & 26.09 & 35 & 38.04 & 18 & 19.57 & 8 & 8.70 & 92 & 100.00 \\
\hline 8.I avoid overworking & 11 & 11.96 & 24 & 26.09 & 32 & 34.78 & 16 & 17.39 & 9 & 9.78 & 92 & 100.00 \\
\hline $\begin{array}{l}\text { 12.I check weight of my } \\
\text { body }\end{array}$ & 13 & 14.13 & 21 & 22.83 & 17 & 18.48 & 24 & 26.09 & 17 & 18.48 & 92 & 100.00 \\
\hline 16. I sleep enough & 9 & 9.78 & 10 & 10.87 & 29 & 31.52 & 26 & 28.26 & 18 & 19.57 & 92 & 100.00 \\
\hline $\begin{array}{l}\text { 20.I try to cut down on } \\
\text { smoking }\end{array}$ & 22 & 23.91 & 12 & 13.04 & 13 & 14.13 & 12 & 13.04 & 33 & 35.87 & 92 & 100.00 \\
\hline $\begin{array}{l}\text { 24.I avoid excessive physi- } \\
\text { cal effort }\end{array}$ & 7 & 7.61 & 13 & 14.13 & 36 & 39.13 & 24 & 26.09 & 12 & 13.04 & 92 & 100.00 \\
\hline
\end{tabular}

Source: own elaboration.

The proportion of responses where respondents barely ever evinced health practice was $12.5 \%$, while a higher proportion of $17.57 \%$ of the responses indicated that respondents almost always tried to take care of their physical health.

The study showed that health behaviours of patients with cirrhosis were mediocre and were within 5-7 Sten. During the analysis of health behaviours it was verified that positive mental attitude and proactive behavior were estimated the best, while good nutrition and health practice were evaluated worse. The results are presented in table 6 . 
Table 6. General grade of respondents' health behaviours

\begin{tabular}{|c|c|c|c|c|}
\hline Health behaviours & Average & Min. & Max & Std dev. \\
\hline Correct nutrition habits & 3.14 & 1.33 & 5.0 & 0.87 \\
\hline Proactive behaviours & 3.24 & 1.00 & 5.0 & 0.98 \\
\hline Positive mental attitude & 3.44 & 1.67 & 5.0 & 0.68 \\
\hline Health practice & 3.13 & 1.33 & 5.0 & 0.81 \\
\hline IZZ & 77.66 & 37.00 & 110.0 & 16.72 \\
\hline
\end{tabular}

Source: own elaboration.

Statistical analysis showed significant differences in the intensity of declared proactive behaviours between women and men $(\mathrm{p}=0.03)$. It was claimed that women had higher intensity of healthy correct nutrition habits, $(p=0.01)$ and proactive behaviours $(p=0.03)$. In other health areas that were analyzed, the research showed no significant differences between men and women $(\mathrm{p}>0.05)$. The results are presented in table 7.

Table 7. Health behaviours according to gender

\begin{tabular}{|c|c|c|c|c|c|c|}
\hline \multirow{2}{*}{ Health behaviours } & \multicolumn{2}{|c|}{ Men } & \multicolumn{2}{c|}{ Women } & \multicolumn{2}{c|}{ Statistical analysis } \\
\cline { 2 - 7 } & Average & Std dev. & Average & Std dev. & \multicolumn{1}{c|}{ t } & p \\
\hline Correct nutrition habits & 2.91 & 0.95 & 3.38 & 0.69 & -2.70 & $0.01^{*}$ \\
\hline Proactive behaviours & 3.03 & 0.95 & 3.48 & 0.96 & -2.24 & $0.03^{*}$ \\
\hline Positive mental attitude & 3.32 & 0.76 & 3.57 & 0.56 & -1.83 & 0.07 \\
\hline Health practice & 3.11 & 0.89 & 3.16 & 0.71 & -0.33 & 0.75 \\
\hline IZZ & 74.08 & 18.10 & 81.57 & 14.28 & -2.19 & $0.03^{*}$ \\
\hline
\end{tabular}

Source: own elaboration.

Respondents at the age of 51 years or more had the best health behaviours in each aspect of the study. As a result of statistical analysis, significant differences in intensity of health behaviours between age groups ( $p$ $=0.05)$ were indicated. Significant differences were verified in the intensity of health practices, $(p=0.0009)$, instead in other behaviours, there were no significant differences between age groups. The results are presented in table 8.

Table 8. Health behaviours according to age groups

\begin{tabular}{|c|c|c|c|c|c|c|c|}
\hline \multirow[b]{2}{*}{ Health behaviors } & \multicolumn{2}{|c|}{ to 40 years } & \multicolumn{2}{|c|}{ 41-50 years } & \multicolumn{2}{|c|}{51 years and more } & \multirow[b]{2}{*}{$\begin{array}{l}\text { Statistical } \\
\text { analysis }\end{array}$} \\
\hline & 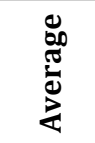 & $\frac{\vec{d}}{0}$ & 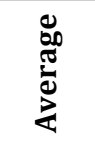 & 总 & 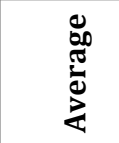 & 旁 & \\
\hline Correct nutrition habits & 3.03 & 0.95 & 3.03 & 0.88 & 3.36 & 0.73 & $\mathrm{~F}=1.46 ; \mathrm{p}=0.24$ \\
\hline Proactive behaviours & 3.15 & 1.06 & 3.10 & 0.96 & 3.50 & 0.87 & $\begin{array}{l}\mathrm{F}=1.49 \\
\mathrm{p}=0.23\end{array}$ \\
\hline Positive mental attitude & 3.33 & 0.64 & 3.44 & 0.66 & 3.57 & 0.75 & $\mathrm{~F}=0.97 ; \mathrm{p}=0.38$ \\
\hline Health practice & 2.93 & 0.70 & 2.93 & 0.79 & 3.59 & 0.79 & $\mathrm{~F}=7.59 ; \mathrm{p}=0.0009^{*}$ \\
\hline IZZ & 74.65 & 16.67 & 74.93 & 16.41 & 83.93 & 15.89 & $\mathrm{~F}=3.12 ; \mathrm{p}=0.05^{*}$ \\
\hline
\end{tabular}

Source: own elaboration.

Statistical analysis showed no significant differences in the intensity of good nutrition among education groups ( $\mathrm{p}>0.05)$. The best eating habits were noted among respondents with master's and bachelor education and the worst among those with basic or vocational education. The results are presented in table 9. 
Table 9. Health behaviours between education groups

\begin{tabular}{|c|c|c|c|c|c|c|c|}
\hline \multirow[b]{2}{*}{ Health behaviours } & \multicolumn{2}{|c|}{ basic/ vocational } & \multicolumn{2}{|c|}{$\begin{array}{c}\text { secondary/ } \\
\text { bachelor }\end{array}$} & \multicolumn{2}{|c|}{$\begin{array}{l}\text { incomplete hi- } \\
\text { gher/ higher }\end{array}$} & \multirow[b]{2}{*}{$\begin{array}{l}\text { Statistical } \\
\text { analysis }\end{array}$} \\
\hline & 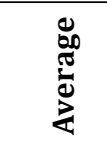 & 旁 & 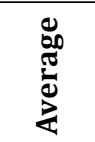 & 胥 & $\begin{array}{l}0 \\
0 \\
0 \\
0 \\
0\end{array}$ & $\frac{\vec{\partial}}{0}$ & \\
\hline Correct nutrition habits & 2.99 & 0.93 & 3.26 & 0.85 & 3.10 & 0.85 & $\mathrm{~F}=0.74 ; \mathrm{p}=0.48$ \\
\hline Proactive behaviours & 3.22 & 0.98 & 3.47 & 1.02 & 2.99 & 0.88 & $\mathrm{~F}=2.13 ; \mathrm{p}=0.12$ \\
\hline Positive mental attitude & 3.47 & 0.71 & 3.52 & 0.68 & 3.32 & 0.66 & $\mathrm{~F}=0.77 ; \mathrm{p}=0.47$ \\
\hline Health practice & 3.25 & 0.88 & 3.28 & 0.76 & 2.87 & 0.77 & $\mathrm{~F}=2.57 ; \mathrm{p}=0.08$ \\
\hline IZZ & 77.42 & 17.20 & 81.19 & 16.72 & 73.65 & 15.93 & $\mathrm{~F}=1.75 ; \mathrm{p}=0.18$ \\
\hline
\end{tabular}

Source: own elaboration.

There were no significant differences in the assessment of health behaviours between respondents from the city and from the countryside, ( $p>0.05)$. However, patients from rural areas had slightly better mental attitude, the level of proactive behaviours and general assessment of health behaviours compared to the respondents from small and large cities. The results are presented in table 10.

Table 10. Health behaviours connected with place of residence

\begin{tabular}{|c|c|c|c|c|c|c|c|}
\hline \multirow[b]{2}{*}{ Health behaviours } & \multicolumn{2}{|c|}{$\begin{array}{l}\text { City-to } 100 \text { thou- } \\
\text { sands of residents }\end{array}$} & \multicolumn{2}{|c|}{$\begin{array}{c}\text { City-over } 100 \\
\text { thousands of resi- } \\
\text { dents }\end{array}$} & \multicolumn{2}{|c|}{ Village } & \multirow{2}{*}{$\begin{array}{l}\text { Statistical } \\
\text { analysis }\end{array}$} \\
\hline & 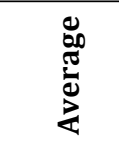 & $\frac{\vec{d}}{2}$ & 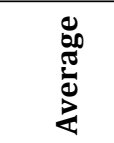 & 完 & 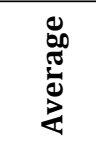 & 胥 & \\
\hline Correct nutrition habits & 3.30 & 0.87 & 2.99 & 0.92 & 3.07 & 0.77 & $\mathrm{~F}=1.20 ; \mathrm{p}=0.31$ \\
\hline Proactive behaviours & 3.30 & 1.07 & 2.98 & 0.80 & 3.51 & 0.99 & $\mathrm{~F}=2.12 ; \mathrm{p}=0.13$ \\
\hline Positive mental attitude & 3.47 & 0.61 & 3.32 & 0.61 & 3.53 & 0.86 & $\mathrm{~F}=0.74 ; \mathrm{p}=0.48$ \\
\hline Health practice & 3.10 & 0.81 & 3.07 & 0.85 & 3.27 & 0.76 & $\mathrm{~F}=0.47 ; \mathrm{p}=0.63$ \\
\hline$I Z Z$ & 79.03 & 17.15 & 74.00 & 15.15 & 80.29 & 17.85 & $F=1.17 ; p=0.32$ \\
\hline
\end{tabular}

Source: own elaboration.

There were no significant differences in the assessment of health behaviours between the groups taking into account the time of diagnosis of liver disease ( $p>0.05)$. However, it was noted that the respondents who were ill for the shortest time had slightly better health practice, proactive behaviours and good nutrition, also the general assessment of health behaviour. The results are presented in table 11.

Table 11. Health behaviours connected with the time of the first diagnosis

\begin{tabular}{|c|c|c|c|c|c|c|c|}
\hline \multirow[b]{2}{*}{ Health behaviours } & \multicolumn{2}{|c|}{ 1-5 years } & \multicolumn{2}{|c|}{$5-10$ years } & \multicolumn{2}{|c|}{ over 10 years } & \multirow[b]{2}{*}{$\begin{array}{l}\text { Statistical } \\
\text { analysis }\end{array}$} \\
\hline & 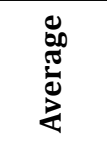 & 总 & 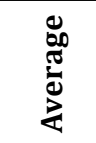 & 总 & 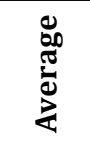 & $\frac{\dot{z}}{\tilde{D}}$ & \\
\hline Correct nutrition habits & 3.32 & 0.79 & 2.92 & 0.92 & 3.18 & 0.86 & $\mathrm{~F}=1.96 ; \mathrm{p}=0.15$ \\
\hline Proactive behaviours & 3.38 & 1.01 & 3.11 & 0.91 & 3.23 & 1.04 & $\begin{array}{l}F=0.66 \\
p=0.52\end{array}$ \\
\hline Positive mental attitude & 3.42 & 0.69 & 3.41 & 0.73 & 3.51 & 0.60 & $\mathrm{~F}=0.14 ; \mathrm{p}=0.87$ \\
\hline Health practice & 3.25 & 0.65 & 3.05 & 0.95 & 3.07 & 0.82 & $F=0.66 ; p=0.52$ \\
\hline IZZ & 80.22 & 15.05 & 74.83 & 18.11 & 77.90 & 17.20 & $\mathrm{~F}=0.94 ; \mathrm{p}=0.40$ \\
\hline
\end{tabular}

Source: own elaboration. 


\section{Discussion}

In $30-40 \%$ of patients, cirrhosis runs completely asymptomatic and is detected incidentally during tests for other reasons. With progression of the disease the physical and intellectual capacity of patients worsens (Wawrzynowicz-Syczewska 2011). It becomes necessary to change lifestyle, leave the profession, retire. These situations can cause and exacerbate family conflicts, prompt negative emotions such as sadness, despondency or depression.

The study showed that health behaviours of patients with cirrhosis were mediocre. It was noted that most respondents cared about positive mental attitude (3.44) and proactive behaviours (3.23), and less did about good nutrition (3.14) and health practice (3.13). Positive eating habits and proactive behaviours are very important elements of proper treatment of cirrhosis.

The analysis of data shows that the proportion of responses where respondents barely ever evinced positive eating habits and proactive behaviours was 15\%, while the proportion of respondents who lmost always evinced them was higher and amounted to respectively $18.3 \%$ and $22.46 \%$. Avoiding excessively strong emotions, stress and tension, care for one's health, orderly life are the criteria that comprise the positive mental attitude. Proportion of all responses where respondents almost always cared about positive mental attitude was 19.92\%. Health behaviours during the disease depend on such conditions as: age, gender, aims of life, the social situation (among other things: social roles performed, origin, education, material conditions, place of residence) and cultural situation (among other things: world view, family traditions, national , customs) (Banaszkiewicz, Andruszkiewicz 2008). The present study evaluated the impact of some of the studied traits on health behavior, yielding correlations with gender, age, education, disease duration and place of residence (Banaszkiewicz, Andruszkiewicz 2008).

Statistical analysis showed significant differences in the intensity of declared proactive behaviours between women and men $(p=0.03)$. It was claimed that women had higher intensity of healthy good nutrition, $(p=0.01)$ and proactive behaviours $(\mathrm{p}=0.03)$. Other health areas that were analyzed, showed no significant differences between men and women ( $p>0.05)$.As a result of statistical analysis, significant differences in intensity of health behaviours between age groups $(p=0.05)$. ) were spotted. Significant differences were verified in the intensity of health practices, ( $\mathrm{p}=0.0009)$, whilst in other behaviours, there were no significant differences between age groups. Respondents at the age of 51 years or more had the best health behaviours in each aspect of the study. Statistical analysis showed no significant differences in the intensity of good nutrition among education groups ( $p>0.05$ ). The best eating habits were identified among respondents with master's and bachelor education and the worst in case of those with basic or vocational education.

There were no significant differences in the assessment of health behaviours between respondents from the city and from the countryside, ( $p>0.05)$. However, respondents from rural areas had slightly better mental attitude, the level of proactive behaviours and general assessment of health behaviours compared to the respondents from small and large cities.

There were no significant differences in the assessment of health behaviours between the groups taking into account the time of diagnosis of liver disease ( $p>0.05)$. However, it was noted that the respondents who were ill for the shortest time had slightly better health practice, proactive behaviours and good nutrition, as well as the general assessment of health behaviour. When comparing it with the research by Gajewska (2003) among her group of studied patients the eating habits were subject to significant change to positive which was evident in caring more about one's diet, nutrition quality and compliance with medical recommendations.

\section{Conclusions}

The study group was characterized by average health behaviours, the results were within the 5 and 6 Sten.

Studies have shown a higher intensity of health behaviours in the category of a positive mental attitude and proactive behaviour, while less intensity in the category of good nutrition and health practice.

Statistically significant differences were shown between health behaviour and gender and age of the respondents. Women had significantly higher intensity of proper eating habits and proactive behaviours. Respondents at the age of 51 years or more had the best health behaviours in all the categories which surveyed health behaviors.

The study showed no statistically significant differences between health behaviour and the time from diagnosis, place of residence, and education of the respondents. 


\section{References:}

1. Banaszkiewicz M.,Andruszkiewicz A.(2008), Zachowaniazdrowotne, In: A.Andruszkiewicz, B. Banaszkiewicz, (eds.), Promocja zdrowia, Czelej, Lublin.

2. Gajewska D. (2003), Zachowania żywieniowe osób z przewlekłymi schorzeniami wątroby. Annales Universitatis Mariae Curie-Skłodowska Lublin - Polonia, Vol. LVIIII, Suppl.XIII,68, Sectio D, p. 376-380.

3. Gniazdowski A. (ed.) (1990), Zachowania zdrowotne. Zagadnienia teoretyczne, próba charakterystyki zachowań zdrowotnych społeczeństwa polskiego. IMP, Łódź.

4. Juczyński Z. (2009), Narzędzia pomiaru w promocji i psychologii zdrowia, Pracownia Testów Psychologicznych, Warszawa.

5. Mach T. (2005), Marskość wątroby, In: J. Daniluk, G. Jurkowska (eds.), Zarys chorób wewnętrznych. Czelej, Lublin, p. 284-295.

6. Romanowska-Tołłoczko A. (2011), Styl życia studentów oceniany w kontekście zachowań zdrowotnych. Hygeia Public Health, 46 (1), p. 89-93.

7. Wawrzynowicz-Syczewska M. (2011), Marskość wątroby, In: A. Szczeklik (ed.), Choroby wewnętrzne. Medycyna Praktyczna, Kraków.

8. Żołnierczuk-Kieliszek D. (2002), Zachowania zdrowotne i ich zwiqzek ze zdrowiem, In: T. Kulik, M. Latalski (eds.), Zdrowie Publiczne. Czelej, Lublin.

9. Ostrowska A. (1999), Styl życia a zdrowie. Wydawnictwo IFiS PAN, Warszawa.

Submitted: 22.10 .2014

Accepted: 22.07.2015 